\title{
COMPARATVE CHICKEN GENOME ANALYSIS OF EGYPTION LOCAL BREEDS AND DEVELOPED STRAINS 5-THE MICROSATELLITE DISCRIMINATION BETWEEN MATROUH, EL-SALAM AND BANDARAH STRAINS \\ Roushdy, Kh. ${ }^{1}$, M.A. El-Sayed ${ }^{2}$ and A.A. Bakir ${ }^{3}$
}

1. Anim. Prod. Res. Inst., and National Gene Bank, Agric. Res. Center, Giza, Egypt.

2. National Gene Bank and Genetic Resources, Agric. Res. Center, Giza, Egypt.

3. Anim.Prod.Res.Inst., Agric.Res.Center,Giza,Egypt. Corresponding author:khromod@yahoo.com

\begin{abstract}
The aim of this study was to compare the genetic variation of three developed chicken strains (Matrouh, El-Salam and Bandarah). Nine highly polymorphic microsatellite markers were used in 133 birds. One hundred fifteen alleles were detected in the overall populations with a mean number of 12.78 alleles per locus. The highest number of alleles was 24 for microsatellite marker MCW 49. While, ADL171 and MCW 43 loci recorded lowest number of alleles across all populations (8). Dendrogram was generated from estimates of genetic distance among chicken populations. Mean number of alleles per strains overall loci ranged from 4.00 for Bandarah to 4.44 for Matrouh. Number of specific alleles was 8 for all strains studied and effective number of allele (ENA) ranged from 1.49 for MCW43 to 4.95 for MCW49. Averages of expected heterozygosity $\left(H_{E}\right)$ were $0.597,0.601$ and 0.607 for Matrouh, El-Salam and Bandarah chicken populations, respectively. Dendogram Based Nei's genetic distance revealed that Matrouh and Bandarah chicken populations are closely related than that of El-Salam.The study revealed the existence of moderate genetic diversity in chicken populations studied and also showed that the markers used were highly informative and can be used in future studies involving breeding, management and conservation of chicken populations.

Keywords: Genotypic diversity, heterozygosity, number of alleles, effective number of alleles, microsatellite markers, local breeds.
\end{abstract}

\section{INTRODUCTION}

In recent years, animal biodiversity management has become an important issue in the international scientific community because of changes in large-scale production systems (FAO, 2007). In North America, Europe and China about $50 \%$ of documented breeds are classified as extinct, critical or endangered (Hammond, 1996) and local breeds have often been diluted by indiscriminate cross-breeding with imported stocks (FAO, 2007). The reduction in local poultry breeds due to replacement with cosmopolitan ones suggests a need for conservation of local genetic resources.

As for conservation of livestock genetic resources, if there are limitations of costs or breeding places, the population may be maintained as a core collection, which possesses as much genetic variability as possible 
with appropriate population size. To develop the core collection, exact genetic evaluation for the population would be required by molecular markers. It would lead to a correct management of the population as a genetic resource (FAO, 1998).

Evaluation of genetic diversity for local breeds is becoming more challenging, and large efforts have been concentrated on maintaining minimum number of animals for each native species (FAO, 2007). Molecular marker information may provide reliable estimates of genetic diversity within and between a given set of populations. It is useful to explore genetic diversity within and between breeds or populations to analyze genetic relationships and admixtures and to provide information on evolutionary relationships and parentage within populations. Moreover, for breeds undergoing conservation, molecular data should be integrated with other information (i.e., adaptative, productive and reproductive performances; extinction probabilities) to guide decision makers (Zanatti et al., 2010).

The microsatellite marker as molecular marker is extensively used for assessing genetic structure, diversity, and relationships because of many advantages such as being numerous and ubiquitous throughout the genome, showing a higher degree of polymorphisms and codominant inheritance (Tautz, 1989). Especially, high degree of polymorphisms is considered to be greatly useful for assessing genetic diversity and relationships among closely related livestock breeds (FAO, 1998). Thus, use of microsatellite markers has become a standard method to estimate genetic diversity indices in all livestock species. However, some investigators have used microsatellites across Egyptian chicken populations ( Roushdy et al., 2008, 2009 and 2012 a,b ; El-Sayed et al., 2011; El-Tanany, 2011and Ramdan et al., 2012).

Matrouh chicken was developed from a cross between the White Leghorn and Dokki-4 for six generations using systems of breeding coupled with selection (Mahmoud et al., 1974). The White Cornish and the Gimmizah were utilized as base population when developing Bandarah chicken for four generations. More than six years were devoted for developing this breed of chicken. This breed could be utilized as foundation stock for meat production (Mahmoud et al., 1989). El-Salam strain was designed for meat production. Originating from a cross between Nichol sires (parent line) and Mamourah females, selected for meat production, this strain is characterized by a broad breast and a keel that is carried forward (Abd El-Gawad et al.,1983).

The objective of this study was to investigate and compare genetic variance and diversity with 9 microsatellite loci in 3 Egyptian chicken populations (Matrouh, El-Salam and Bandarah).

\section{MATERIALS AND METHODS}

Chicken populations, blood sampling and DNA isolation:

Three Egyptian local strains, Matrouh, El-Salam and Bandarah chickens were assayed in the present investigation. A total of 133 individuals 
were used from the three strains. Blood samples and DNA isolation were carried out as previously described by Roushdy et al. (2009).

\section{Microsatellite loci, PCR and amplification conditions:}

Nine microsatellite loci (Table 1) were selected based on the degree of polymorphism and genome coverage that have been recommended for the measurement of Domestic Animals Diversity (DAD) (FAO, 2004), for application in diversity studies. Detailed information about used microsatellites is available at the FAO website (Error! Hyperlink reference not valid.en/refer/library/guidelin/marker.pdf). The PCR reactions were carried out in a volume of $20 \mu \mathrm{l}$ as described by Roushdy et al. (2009).

\section{Microsatellite and genetic analysis:}

All resulted gels were visualized and scored with Alphaimages2200 software (Version 4.0.1) All scored microsatellite data was firstly corrected to estimate each allele size according to its number of repeats. A Tandem Repeat Analyzer software package was adopted for this purpose. All possible extracted population figures were carried out employing a Arlequin 3.51 software package after data conversion using Convert program. It is common in such cases no amplicon is produced in certain samples for such primer rather than other. Thus, the absence of PCR product in these samples is manipulated as missing data. As a consequent, the analysis program accounts them as null (unknown) alleles not exceeded 0.1 of data as our default analysis.

\section{RESULTS AND DISCUSSION}

A set of nine highly polymorphic SSR markers were attended in the present investigation. Table(1) summarizes all information of the microsatellites markers used and shows locus name, gene bank NCBI accession number, genome location, microsatellite repeat type, flanking sequences, annealing temperature, reported number of alleles and sequence tagged site (STS) size in base pairs.

The genetic variability of the microsatellite loci is summarized in Figures (1and2). One hundred fifteen alleles were detected across 9 loci in three chicken populations with mean number of alleles per locus of 12.78. Locus MCW49 was highly polymorphic with 24 alleles, while ADL171 and MCW43 loci had the lowest polymorphism (8 alleles per locus). 
Roushdy, Kh.et al.

$\mathrm{T} 1$ 
Results of this study indicated that most of the selected loci were reliable and informative because mean number of alleles per locus were more than four (Nassiri et al.,2007, 2009). Correspondingly, the standard error in the estimation of genetic distances were reduced (Nassiri et al., 2007).

The mean number of alleles per locus calculated for three chicken populations was 12.78 and was nearly similar to the value of 14.00 recorded in 20 chicken breeds based on 14 markers shared with our study (Rosenberg et al., 2001). Similar results were reported by Roushdy et al. (2012a), who investigated the value of 12 alleles for the discrimination between Dandrawi and Sinai breeds. On the other hand our value was greater than 10 reported for 52 chicken populations with 12 shared markers from a set of 22 markers (Hillel et al., 2003), 10.11 reported for six South African local chicken lines based on nine markers (Van Marle-Köster et al., 2008), 10.33 reported for six Indian chicken populations based on three markers (Pirany et al., 2007) and 11.4 in 64 populations of chickens from different continents by Granevitze et al. (2007). Lower estimates of mean number of alleles per locus were reported also by Farrag et al. (2013) as 5.66 in their study on genetic variation between Sinai chicken and Japanese quail and 7.5 for five subpopulations of Turkish native chicken breeds (Kaya and Yildiz, 2008). Population-specific alleles and/or allele scoring bias (allele dropout, null alleles) could explain these discrepancies in the number of alleles/locus (Nassiri et al., 2007).

Effective number of alleles used to corollary the expected heterozygosity (when heterozygosity is high, ENA will be highest). The lowest ENA was 1.49 for MCW43 when $\mathrm{H}_{\mathrm{E}}$ was 0.26 while, the highest ENA was 4.95 for MCW49 when $\mathrm{H}_{\mathrm{E}}$ was 0.79 (Fiures 1and2). Same trend was reported by Roushdy et al. (2012b) for two populations of chicken (Gimiza and Inshas), the lowest ENA was 2.17 for MCW43 when $\mathrm{HE}_{\mathrm{E}}$ was 0.48 , while the highest ENA was 10.05 for ADL176 when $\mathrm{HE}_{\mathrm{E}}$ was 0.83 .

According to classification of Botstein et al. (1980) and Ott (2001), the highly informative markers have PIC values $>0.50$, the reasonably informative markers have PIC value between $0.25-0.50$ and the slightly informative markers have PIC value $<0.25$. Six markers in the current study had highly informative PIC values of $0.55,0.62,0.66,0.53,0.54$ and 0.63 for ADL136, ADL172, ADL176, ADL210, MCW49 and MCW51, respectively, and the rest of markers had reasonably informative markers. Similarly, in Turkish native chicken breeds, polymorphism information content varied from 0.426 to 0.599 (Kaya and Yildiz., 2008). Also, the investigation had done by Roushdy et al. (2012 b) showed that PIC values ranged from 0.3 to 0.79 and averaged 0.62 in Gimiza strain, while in Inshas ranged from 0.49 to 0.73 and averaged 0.66. Same findings obtained by Farrag et al. (2013), who found PIC ranged between 0.52 and 0.81 with average of 0.64 in Sinai chicken and Japanese quail, respectively. Pham et al. (2013) reported PIC average of 0.57 for 10 Taiwan commercial native chicken populations, two exotic breeds and one red jungle fowl population. 
The $\mathrm{H}_{\mathrm{E}}$ for all loci was $>0.50$ and supported the effectiveness of the selected loci. The $\mathrm{H}_{\mathrm{O}}$ and $\mathrm{H}_{\mathrm{E}}$ ranged from 0.000 (MCW43) to 0.763 (ADL172) and 0.264 (MCW43) to 0.793 (MCW49), respectively. For all loci, the mean $\mathrm{H}_{\mathrm{E}}$ was higher than the mean $\mathrm{H}_{\mathrm{O}}$ (Figure 2), which suggested sampling bias or a possible inbreeding mating system.

Table (2) summarizes the genetic variation across populations. The $\mathrm{H}_{\mathrm{E}}$ variations were $0.597,0.601$ and 0.607 for Matrouh, El-Salam and Bandarah populations, respectively. These results are in agreement with Roushdy et al. (2012a) for Dandrawi (0.67) and Sinai (0.73)breeds, Roushdy et al. (2012b) for Gimiza (0.67) and Inshas (0.72) strains and Pham et al.(2013) for 10 Taiwan commercial native chicken populations, two exotic breeds and one red jungle fowl population (0.63). The Ho variations were $0.548,0.310$ and 0.405 for Matrouh, El-Salam and Bandarah populations, respectively.

Population fixation indices traced a 0.445 of variation referring to differences among individuals versus total variance $\left(F_{I T}\right)$. While, among populations differences versus total variance was the lowest fixation indices ( $\left.F_{S T}=0.209\right)$ indicating low level of population differentiation. A pair wise difference among Matrouh, El-Salam and Bandarah populations was 0.299 based on among breeds $F$ index (FIS). The results are in agreement with Roushdy et al. (2012a) for Dandrawi and Sinai breeds, Roushdy et al. (2012b) for Gimiza and Inshas strains.

The genetic diversity among strains was assessed by an analysis of molecular variance (F-indices) employing Arlequin 3.51 software package as standard genetic population input data. The Wright fixation indices for $F_{I S}$ ranged from -0.123 (ADL172) to 1.00 (MCW43), Fst ranged from 0.0286 (ADL172) to 0.3299 (ADL171) and $F_{I T}$ ranged from -0.0960 (ADL172) to 1.000 (MCW43), with means of $0.2929,0.1593$ and 0.4055 , respectively (Table 6). A high positive $F_{I S}$ indicated a high degree of observed homozygosity (MCW43) while there was excessive heterozygosity at locus ADL172, as indicated by the negative FIs value. Significant deviations from HWE $(p<0.5)$ were observed across 2 populations (EI-Salam, 0.002 and Bandarah, 0.04) for all loci except for Bandarah at ADL210 locus (0.42).

Table (3) showed the common and specific alleles for Matrouh, ElSalam and Bandarah populations. The specific and common alleles were 24 and 37, respectively. These specific alleles could be used as fingerprint for these chicken populatins.

Table (4) presents analysis of molecular variance (AMOVA). Variance components proved that the majority of genetic diversity obtained in the current study is represented by within individuals $(55.46 \%)$ rather than others.

Cluster analysis based on Nei's genetic distance indicated that the studied populations formed two main groups (Fig. 5). The $1^{\text {st }}$ group included Matrouh and Bandarah and the $2^{\text {nd }}$ group harbored El-Salam.

Although genetic analyses can reveal the extent of biodiversity in chicken breeds (Nassiri et al., 2007;Semik and Krawczyk, 2011) additional information on specific adaptations, distinct phenotypes, performance level, demography(including effective population size,and geographical distribution), and descriptive databases are required for adequate assessment of each breed when deciding on conservation and breeding programs (Groeneveld et al., 2010). 


\section{CONCLUSION}

the 9 microsatellite primers were recommended to assess molecular genetic structure of the local breeds and/or strains in Egypt. The results clearly demonstrated the genetic diversity of these chickens and would serve the appropriate managements on different levels including conservation of such genetic resources, future improvements for these breeds and/or understanding different genome arrangement and knowledge interests.

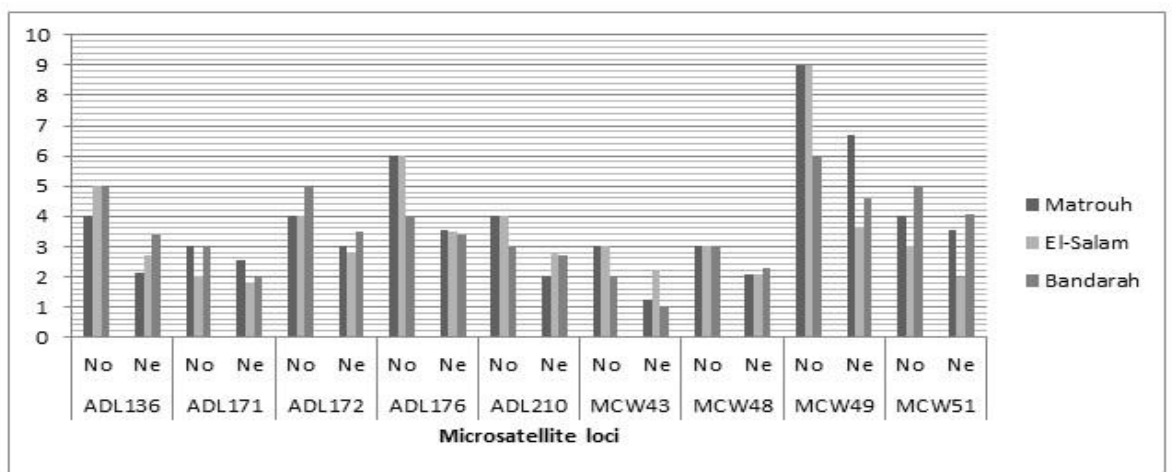

Figure (1): Number of alleles (No), effective number of alleles (Ne) estimated for each locus and strain.

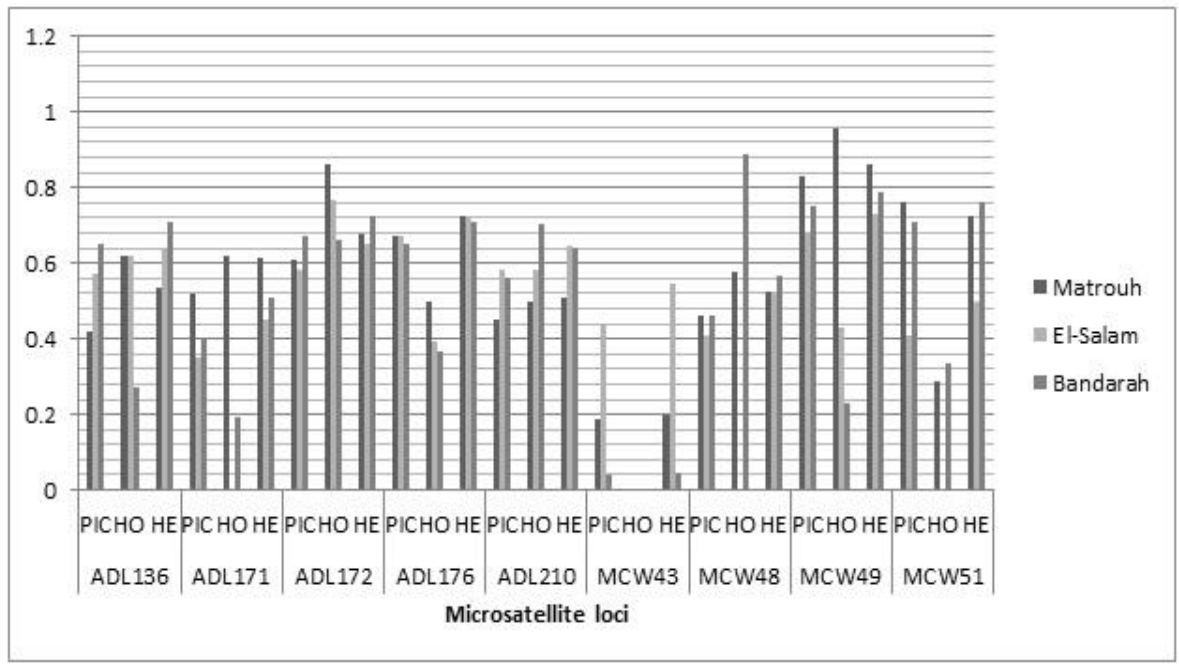

Figure (2): Polymorphism information content (PIC), observed heterozygosity 


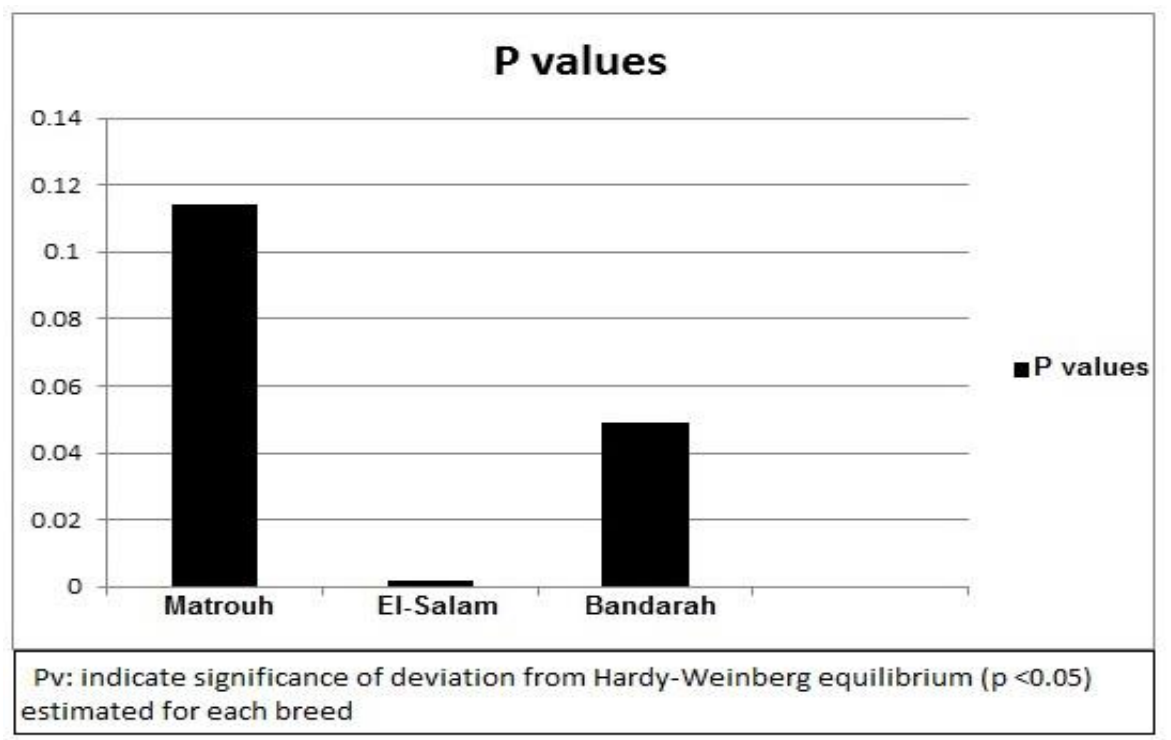

Figure (3): P values estimated for three chicken populations.

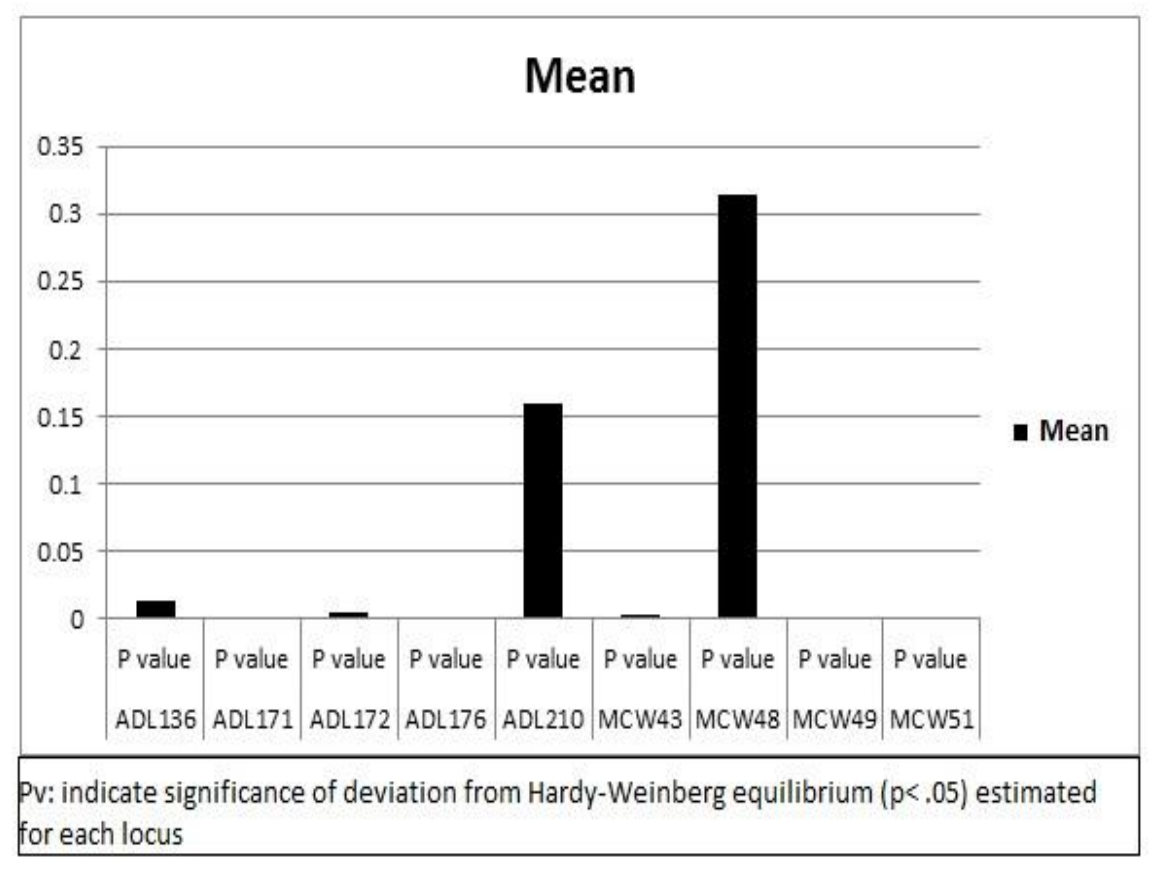

Figure (4) P values estimated for each microsatellite locus. 
Table(2): Observed heterozygosity $\left(\mathrm{H}_{\mathrm{O}}\right)$, expected heterozygosities $\left(H_{E}\right)$ and their means,average population specific, $F_{I S}$ (absolute value)estimated for each population.

\begin{tabular}{|l|c|c|c|c|}
\hline & Matrouh & EI-Salam & Bandarah & Mean \\
\hline Mean $\left(\mathrm{H}_{\mathrm{E}}\right)$ & 0.597 & 0.601 & 0.607 & 0.602 \\
\hline Mean $\left(\mathrm{H}_{\mathrm{O}}\right)$ & 0.548 & 0.310 & 0.405 & 0.421 \\
\hline $\mathrm{IC}$ & 0.082 & 0.484 & 0.333 & \\
\hline Mean $\mathrm{F}_{\mathrm{IS}}$ & 0.142 & 0.536 & 0.380 & 0.352 \\
\hline
\end{tabular}

IC: inbreeding coefficient. $\left(\mathrm{IC}=\left(\mathrm{H}_{\mathrm{E}-} \mathrm{H}_{\mathrm{O}}\right) / \mathrm{H}_{\mathrm{E}}\right)$

Table (3): Common and specific alleles for analyzed breeds Matrouh, EISalam and Bandarah

\begin{tabular}{|l|c|c|c|c|}
\hline \multirow{2}{*}{ Locus } & Common alleles bp & \multicolumn{3}{|c|}{ Specific alleles } \\
\cline { 3 - 5 } & & Matrouh & El-Salam & Bandarah \\
\hline ADL136 & $110,132,154,176,198$ & 88 & -- & 220 \\
\hline DL171 & 90 & 108,126 & 72 & $144,162,180$ \\
\hline ADL172 & $126,144,162,180$ & -- & -- & 198,216 \\
\hline ADL176 & $192,204,216,228$ & 168,180 & 152,240 & -- \\
\hline ADL210 & $120,135,150,165$ & -- & -- & -- \\
\hline MCW48 & $190,208,226$ & -- & $82,100,118$ & -- \\
\hline MCW43 & $111,132,153$ & -- & -- & -- \\
\hline MCW49 & $118,130,142,154,166,178,190,20$ & $226,238,250$ & -- & 106 \\
\hline MCW51 & 2,214 & -- & 70,80 & 130 \\
\hline Total & $90,100,110,120$ & 8 & 8 & 8 \\
\hline
\end{tabular}

Table (4): AMOVA analysis of Matrouh, EI-Salam and Bandarah strains based on microsatellite DNA variation.

\begin{tabular}{|l|c|c|c|c|}
\hline Source of variation & d.f. & S .S. & $\begin{array}{c}\text { Percentage } \\
\text { variation }\end{array}$ & Fixation indices \\
\hline Among populations & 2 & 129.65 & 20.91 & $\mathrm{~F}_{\mathrm{IS}=0.2987}$ \\
\hline within populations & 130 & 446.99 & 23.63 & $\mathrm{~F}_{\mathrm{ST}}=0.2091$ \\
\hline Within individuals & 133 & 247.50 & 55.46 & $\mathrm{~F}_{\mathrm{IT}}=0.4454$ \\
\hline Total Fixation & 265 & 824.15 & ---- & ---- \\
\hline \multicolumn{2}{r}{ F indices } & (Among & populations) \\
\hline
\end{tabular}

$\mathrm{F}_{\mathrm{ST}}$ : Fixation indices (Among individuals within populations)

$\mathrm{F}_{\mathrm{IT}}$ : Fixation indices (Within individuals)

Table(5):Nei's Original Measures of Genetic Identity and Genetic distance.

\begin{tabular}{|l|c|c|c|}
\hline \multicolumn{1}{|c|}{ Population } & Matrouh & El-Salam & Bandarah \\
\hline Matroh & -- & 0.5547 & 0.6616 \\
\hline Salam & 0.5892 & -- & 0.5321 \\
\hline Bandara & 0.4131 & 0.6309 & -- \\
\hline
\end{tabular}

Nei's genetic identity (above diagonal) and genetic distance (below diagonal). 
Table (6): Summary of F-Statistics and Gene Flow for All Loci

\begin{tabular}{|l|c|c|c|}
\hline Locus & Fis & Fit & Fst \\
\hline ADL136 & 0.1876 & 0.3758 & 0.2316 \\
\hline ADL171 & 0.4745 & 0.6478 & 0.3299 \\
\hline ADL172 & -0.1283 & -0.0960 & 0.0286 \\
\hline ADL176 & 0.4100 & 0.4317 & 0.0369 \\
\hline ADL210 & -0.0049 & 0.0659 & 0.0704 \\
\hline MCW48 & 0.0848 & 0.3579 & 0.2985 \\
\hline MCW43 & 1.0000 & 1.0000 & 0.2349 \\
\hline MCW49 & 0.3134 & 0.3702 & 0.0828 \\
\hline MCW 51 & 0.6833 & 0.7263 & 0.1357 \\
\hline Mean & 0.2929 & 0.4055 & 0.1593 \\
\hline
\end{tabular}

Figure (5) : Dendrogram Based Nei's (1978) Genetic distance of three chicken strain produced by UPGMA clustering based on Nei's genetic distance using 9 microsatellite loci.

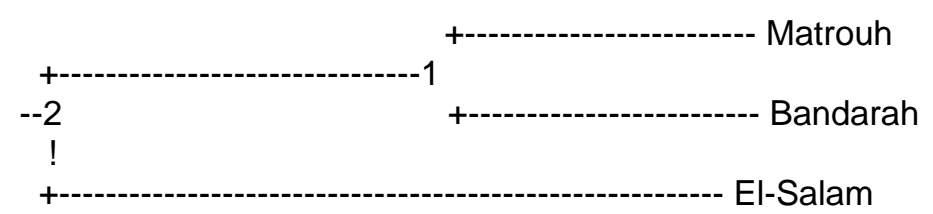

\section{REFERENCES}

Abd El-Gawad, E.M.; M.M. Balat; N. Abou El-Ella; M.M. Ali and K.M. Omran (1983). "El-Salam" a new locally developed strain of chickens. Agric. Res.Rev., 61(6): 147-157.

Botstein, D.; R.L.White; M.Skolnick; R.W. Davis (1980). Construction of a genetic-linkage map in man using restriction fragment length polymorphisms. American Journal of Human Genetics, v.32,p.314-331.

El-Sayed, M.A.; Kh. Roushdy; A.Galal and A.H. El-Attar (2011). Genetic differentiation of two egyptian chicken breeds using 15 microsatellite markers. The $3^{\text {rd }}$ International Conference of Genetic Engineering and Its Applications, Sharm El-Sheikh, Egypt. Oct.,5-8:149-161.

$\mathrm{El}-\mathrm{Tanany}, \mathrm{M}$. (2011). Assessing genetic variation, structure and relationship for six local chicken strains in Egypt with special reference for crossbreeding influence. The $3^{\text {rd }}$ International Conference of Genetic Engineering and Its Applications, Sharm El-Sheikh, Egypt. Oct.,5-8:6590 .

FAO (2004). Secondary guidelines for development of national farm animal genetic resources management plans. Measurement of domestic animal diversity (MoDAD):Recommended microsatellite markers, Rome., Italy. 
FAO (2007). The Stateofthe World's Animal Genetic Resources forFood and Agriculture.Commission onGenetic Resources for FoodandAgriculture.FoodandAgricultureOrganizationofthe United Nations, Rome,Italy.

FAO(1998).Secondaryguidelinesfordevelopmentofnationalfarmanimalgeneticr esource management plans. Measurement of Domestic Animal Diversity (MoDAD): Original Working GroupReport.FAO, Roma, Italy.

FAO: www.dad.fao.org/en/ refer/library/guidelin/marker.pdf).

Farrag, S.A.; M.E. Soltan and A.A. Enab (2013). Genetic variation analysis of Sinai chicken and Japanese quail populations using microsatellite DNA markers. International Conference on Food and Agricultural Sciences. IPCBEE Vol.55(3): 12-17.

Granevitze Z; J; Hillel; GH; Chen; Cuc NTK, Feldam M, Eding H and Weigend $S$ (2007). Genetic diversity within chicken populations from different continents and management histories. Anim Genet 38:576-583.

Groeneveld LF, J.A, Lenstra, H. Eding M.A. Toro; B. Scherf; D. Pilling; R. Negrini; EK Finlay; H. Jianlin; E. Groeneveld et al. (2010). Genetic diversity in farm animals - A review. Anim Genet 41(Suppl 1):6-31.

Hammond, K. (1996). The status of global farm animal genetic resources. Proceedings of the Symposium on the Economics of Valuation and Conservation of Genetic Resources for Agricul- ture. Centre for International Studies on Economic Growth, Tor Vergata University, Rome, Italy.

Hillel J, A.M. Martien; A.M. Groenen; M.T. Boichard; B. Abraham; A.B. Korol; L. David; V.M. Kirzhner; T. Burke; A. Barre-Dirief et al. (2003). Biodiversity of 52 chicken population sassessed by microsatellite typing of DNA pools. Genet. Select. E. vol 35:533-57.

Kaya, M. and M.A. Yildiz (2008). Genetic diversity among Turkish native chickens, denizli and gerze, estimated by microsatellite markers. Biochem. Genet.,46: 480-491.

Kaya, M. and M.A. Yildiz (2008). Genetic diversity among Turkish native chickens, denizli and gerze, estimated by microsatellite markers. Biochem. Genet.,46: 480-491.

Mahmoud, T.H.; J.E. Abd El-Hameid and A.I. El-Turkey, (1989). "Bandara" A new breed of chickens. Agric. Res. Rev., 67:229.

Mahmoud, T.H.; Y.H. Madkour; I.F. Sayed and K.M. Harrirah (1974). "Matrouh" A new breed of chicken. Agric.Res.Rev.,52(6):87-96.

Nassiri MTB; Z. Hamid and S. Tavakoli (2007)The investigation of genetic variation at microsatellite loci in Mazandranna- tive chickens. J PoultSci 6:675-678.

Nassiry MR; A. Javanmard and R. Tohidi (2009). Application of statistical procedures for analysis of genetic diversity in domestic animal populations. Am J Anim Vet Sci 4:136-141.

Ott, J. (2001); Analysis of Human Genetic Linkage, (revised ed.). Baltimore: Johns Hopkins University Press 
Pham , M.; W. Chang; C. Berthouly-Salazar; D. Lin; S. Yungrahang; Ch.Wang; Y.Lee; M. Tixier-Boichard and Ch.Chen (2013) Genetic characterization of Taiwan commercial native chickens ascertained by microsatellite markers. J. Poult. Sci., 50: 290-299.

Pirany N.; N.M.N. Romanov; S.P. Ganpule; D. Govindaiah and P. Doddananjat (2007).Microsatellites analysis of genetic biodiversityinIndiachickenpopulations.JPoultSci44:19-28.

Ramadan, Sh.; B.B. Kayang; E. Inoue; K. Nirasawa; H. Hayakawa; S. Ito and M. Inoue-Murawama (2012). Evaluation of genetic diversity and conservation priorities for Egyptian chickens. J.ofAni.Sci. 2:183-90.

Rosenberg N.A.; T. Burke; K. Elo; M.W. Feldman; M.A.M Groenen; J. Hillel; A. MäkiTanila; M. Tixier-Boichard; A. Vignal; K. Wim-mers (2001). Empirical evaluation of genetic clustering methods using multi locus genotypes from 20 chicken breeds. Genetics 159:699-713.

Roushdy, Kh.; A. Zein El-Dein; M.M. Fathi; U.M. Ali and H.M. Assy (2008). Microsatellite Genetic Differentiation Analysis of Two Local Chicken Breeds Compared with Foreign Hy-Line Strain. Int.J.Poult.Sci., 7 (11): 1045-1053.

Roushdy, Kh.; T.M.A. Tantawi and A.A. Bakir (2012a). Comparative chicken genome analysis of Egyptian local breeds and developed strains. 1.The microsatellite discrimination between Dandrawi and Sinai breeds. $3^{\text {rd }}$ Mediterranean Poultry Summit and $6^{\text {th }}$ International Poultry Conference, 26 - 29 March 2012, Alexandria , Egypt.1617 - 1628.

Roushdy, Kh.; T.M.A. Tantawi ; M.A. El-Sayed and A.A. Bakir (2012b). Comparative chicken genome analysis of Egyptian local breeds and developed strains.2.The microsatellite discrimination between Gimizah and Inshas strains. $3^{\text {rd }}$ Mediterranean Poultry Summit and 6th International Poultry Conference, 26 - 29 March 2012, Alexandria , Egypt.1193-1204.

Roushdy, Kh.; T.M.A. Tantawi and E.O.H. Saifelnasr (2009). Genetic diversity assessment of two chickens native breeds using dna molecular markers. 5th International Poultry Conference 10-13 March. TabaEgypt.231-242.

Semik, E. and J. Krawczyk (2011). The state of poultry genetic resources and genetic diversity of hen populations. Ann. Anim. Sci 11:181-191.

Tautz, D.(1989)..Hyper variability of simple sequences as a general source for polymorphic DNA markers. Nucleic Acids Res.17:6463-6471.

Van Marle-Köster, E.; CA. Hefer; L.H. Nel and M.A.M. Groenen (2008). Genetic diversity and population structure of locally adapted South African chicken lines: Implications for conservation. J Anim. Sci., 38:271-281.

Zanetti, E.; M. De Marchi; C.Dalvit ; M. Cassandra (2010). Genetic characterization of local Italian breeds of chickens undergoing in situ conservation. Poultry Science, 89, 420-427. 
مقارنه تحليليه لجينوم الاجاج المصرى المحلى والمستتبط

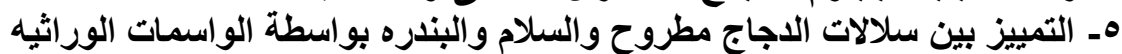

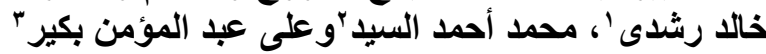

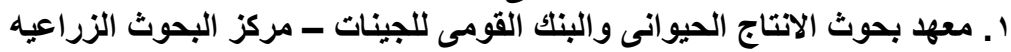

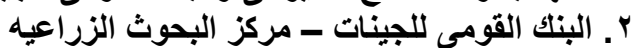

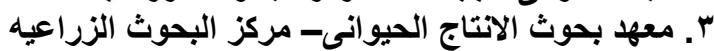

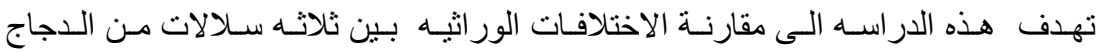

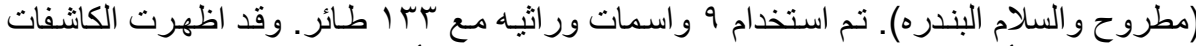

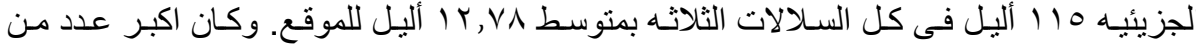

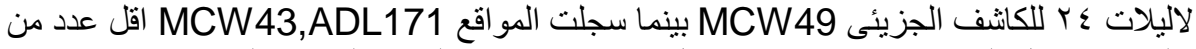

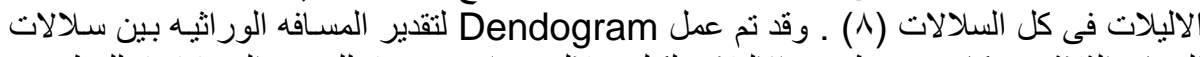

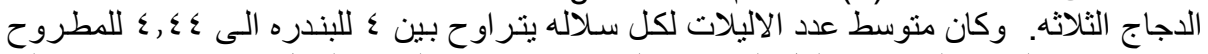

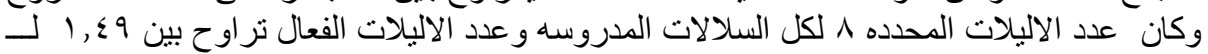

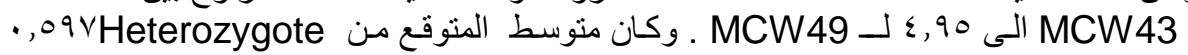

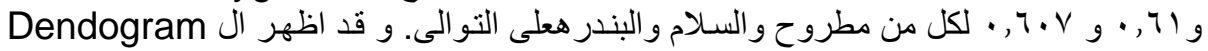

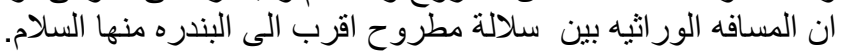

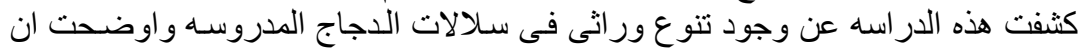

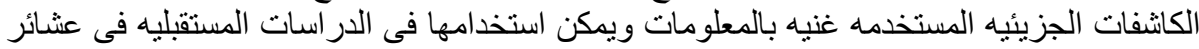
الدجاج فى بر امج التربيه و التحسين الور اثتى والحفظ.

كلية الزراعة - جامعة المنصورة كلية الزراعة - جامعة عين شمس

\section{قام بتحكيم البحث}

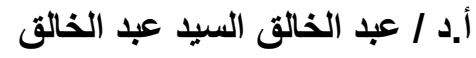

أ.د / اسامة عبد العزيز سليمان 

Table(1): Summarizes all information of nine microsatellite markers used, including locus name, gene bank NCBI accession number, genome location, microsatellite repeat type, flanking sequences, annealing temperature, reported number of alleles and sequence tagged site (STS) size in base pairs.

\begin{tabular}{|c|c|c|c|c|c|c|c|c|c|}
\hline $\begin{array}{l}\text { Locus } \\
\text { Name }\end{array}$ & $\begin{array}{c}\text { Access } \\
\mathrm{No}^{1}\end{array}$ & $\begin{array}{r}\text { Lo } \\
\text { Chr.No }\end{array}$ & $\begin{array}{l}\text { cation }^{2} \\
\text { size range }\end{array}$ & $\begin{array}{c}\text { Repeat } \\
\text { type }\end{array}$ & Forward primer sequence & Reverse primer & $\mathrm{Ta}^{3}$ & $\begin{array}{l}\text { No. of } \\
\text { alleles }^{4}\end{array}$ & $\begin{array}{c}\text { STS } \\
\text { Size }^{5}\end{array}$ \\
\hline ADL0136 & G01561 & 9 & $107 \mathrm{cM}$ & (TG)10 & TGTCAAGCCCATCGTATCAC & ССАССТССТTСТССТGТTСА & 52 & 10 & $145 b p$ \\
\hline ADL0171 & G01593 & 8 & $26: 35 \mathrm{cM}$ & (TG)18 & ACAGGATTCTTGAGATTTTTT & GGTCTTAGCAGTGTTTGTTT & 46 & 8 & $104 \mathrm{bp}$ \\
\hline ADL0172 & G01594 & 8 & $70: 105 \mathrm{cM}$ & $(\mathrm{AC}) 18$ & CCCTACAACAAAGAGCAGTG & CTATGGAATAAAATGGAAAT & 49 & 7 & $154 \mathrm{bp}$ \\
\hline ADL0176 & G01598 & 2 & $116 \mathrm{cM}$ & $(\mathrm{GT}) 12$ & TTGTGGATTCTGGTGGTAGC & TTCTCCCGTAACACTCGTCA & 52 & 9 & $192 \mathrm{bp}$ \\
\hline ADL0210 & G01630 & 11 & $54 \mathrm{cM}$ & $(\mathrm{AC}) 15$ & ACAGGAGGATAGTCACACAT & GCCAAAAAGATGAATGAGTA & 46 & 9 & $130 \mathrm{bp}$ \\
\hline MCW43 & D00311 & 1 & $157 \mathrm{cM}$ & (A)21 & TGACTACTTTGATACGCATGGAGA & CACCAAGTAGACGAAAACACATTT000 & 55 & NA & $154 \mathrm{bp}$ \\
\hline MCW48 & D90071 & 3 & $270 \mathrm{cM}$ & (GT)18 & CGTATAGGAGGGTTTCTGCAGGGA & AAGGAGGAACGCACCGCACCTTCT & 55 & NA & $201 \mathrm{bp}$ \\
\hline MCW49 & M59361 & 1 & $418 \mathrm{cM}$ & (GCA)12 & AGCGGCGTTGAGTGAGAGGAGCGA & TCCCCAACCCGCGGAGAGCGCTAT & 55 & NA & $127 \mathrm{bp}$ \\
\hline MCW51 & M14230 & 2 & $358 \mathrm{cM}$ & $(\mathrm{T}) 10$ & GGAACAAGCTCTTTCTTCTTCCCG & TCATGGAGGTGCTGGTACAAAGAC & 50 & NA & $90 \mathrm{bp}$ \\
\hline
\end{tabular}

1. Gene bank accession number; www.ncbi.nlm.nih.gov/. http://www.ncbi.nlm.nih.gov/genome/sts/sts.cgi?uid=280100

2,4 Locations \& Number of alleles listed as reported by US chicken genome project population tester kit\#9.

3.Annealing temperature, (FAO,2004)

5.STS: sequence tagged site size according to NCBI database. 